\title{
Análise da eficiência de diferentes Veículos na promoção da adesão de Propágulos I nfectivos em Sementes e da colonização de Raízes por Fungo Micorrizico
}

\author{
André Riedi Barazetti ${ }^{1}$, I gor Matheus Oliveira dos Santos ${ }^{1}$, Marcelo Beluca \\ Benite $^{1}$, Vanessa Fogaça de Freitas ${ }^{1}$, Martha Viviana Torres Cely ${ }^{1}$, Admilton \\ Gonçalves de Oliveira $^{1}$ e Galdino Andrade ${ }^{1}$ \\ ${ }^{1}$ Universidade Estadual de Londrina - Departamento de Microbiologia \\ CEP 86051-980 Londrina - Paraná - E-mail: andre.barazetti@yahoo.com.br
}

Introdução: Com o objetivo de formular um inoculante agrícola a base do fungo micorrizico arbuscular (FMA) Rhizophagus Clarus, foram avaliados diferentes materiais que senviram como veículos promovendo à adesão de propágulos infectivos a sementes de soja. O inóculo foi obtido do Laboratório de Ecologia Microbiana - UEL, onde é produzido e mantido em associação com raízes de cenoura transformada. Métodos: A eficiência dos diferentes veículos foi avaliada quanto ao número de fragmentos de hifas, fragmentos de raízes e número de esporos aderidos a sementes de soja, com o auxílio de um microscópio estereoscópico (40X) e quanto à porcentagem de colonização das raízes pelo FMA, avaliada por meio da coloração das raízes, segundo Phyllips e Hayman (1970), e contabilizada pelo método de grid-line (Giovanetti e Mosse, 1980). Para avaliar a adesão dos propágulos infectivos foram analisadas cinco sementes para cada tratamento: Controle (T1); I nóculo + Pó de rocha fosfatada (T2); Inóculo + Turfa (T3); Inóculo + Vermiculita (T4). Enquanto para avaliar a porcentagem de colonização foi realizado um experimento em casa de vegetação, onde foram testados os mesmos quatro tratamentos, cada um com duas repetições. Resultados: Em relação à adesão, dentre os quatro tratamentos o T3 se mostrou mais eficiente, propiciando maior adesão de fragmentos de hifas (146) e fragmentos de raízes (24), porém não foi eficiente quanto à adesão de esporos (4). 0 T2 propiciou maior adesão de esporos (6), porém não foi eficiente quanto a fragmentos de hifas (93) e raízes (3). Em relação à colonização, o T3 apresentou o maior índice de raízes colonizadas (59\%) seguido pelo T4 (46\%). Conclusões: Através deste experimento foi possível verificar que a quantidade de propágulos infectivos aderidos às sementes refletiu diretamente na porcentagem de colonização das raízes de soja, indicando que o T3 foi o que melhor respondeu dentre todos os tratamentos.

Agência de Fomento: Capes

Palavras-chave: inoculante, micorriza, Rhizophagus Clarus, soja. 